\title{
Chemical speciation of dissolved lead in polluted environments. A case of study: the Pontevedra Ria (NW Spain)
}

\section{Especiación química del plomo disuelto en ambientes contaminados. Caso de estudio: la Ría de Pontevedra (NO España)}

\author{
A. Cobelo-García ${ }^{1 *}$ \\ R. Prego ${ }^{1}$ \\ O. Nieto ${ }^{2}$ \\ ${ }^{1}$ Grupo de Bioxeoquímica Mariña \\ Instituto de Investigacións Mariñas (IIM - CSIC) \\ C/ Eduardo Cabello, no 6 \\ 36208 Vigo, España \\ *E-mail: acobelo@iim.csic.es \\ ${ }^{2}$ Departamento de Química Analítica e Alimentaria \\ Facultade de Ciencias \\ Universidade de Vigo \\ Lagoas-Marcosende, $\mathrm{s} / \mathrm{n}$ \\ 36200 Vigo, España
}

Recibido en octubre de 2001; aceptado en octubre de 2002

\begin{abstract}
Chemical speciation of dissolved lead was determined at four sampling sites in the Pontevedra Ría (NW Spain) by differential pulse anodic stripping voltammetry (DPASV) with a HMDE. Sampling location was chosen due to its evident anthropogenic influence: one sample was taken in the Lérez River mouth (2.2-salinity) and other three samples were taken in the surroundings of the village of Marín (salinity 30-32). Lead concentrations were $0.64 \mathrm{nM}$ (river sample) and 4.8-21.9 nM (saline samples). Speciation results showed that organic chelates of lead, $88-95 \%$ of total dissolved lead, are the dominant species of the metal even at these high concentrations. Two types of lead organic complexing ligands were detected in all samples. The river water sample showed the presence of a strong ligand with a concentration of $\sim 7 \mathrm{nM}$ with a conditional stability constant of $\mathrm{K}_{\mathrm{Pb}-\mathrm{L} 1}^{\prime} \geq 10^{11.1}$, and a weaker ligand $\left(\mathrm{K}_{\mathrm{Pb}-\mathrm{L} 2}^{\prime}=10^{8.2}\right)$ with a concentration of $53.4 \mathrm{nM}$. The three saline samples showed similar behavior: a strong ligand $\left(\mathrm{K}_{\mathrm{Pb}-\mathrm{L} 1}^{\prime} \sim 10^{8.6}\right)$ with concentration ranging from 33.0 to $53.5 \mathrm{nM}$, and a weaker complexing ligand $\left(\mathrm{K}_{\mathrm{Pb}-\mathrm{L} 2}^{\prime} \sim 10^{7.5}\right)$ with concentration ranging from 32.6 to $50.5 \mathrm{nM}$. All lead-organic ligand complexes (except the strong complex in the river water sample) showed labile behavior in the time scale of the technique.
\end{abstract}

Key words: Lead, speciation, pollution, rias, Galicia.

\section{Resumen}

La especiación química del plomo disuelto se llevó a cabo en cuatro estaciones de muestreo en la Ría Pontevedra (NO de España) utilizando la técnica de voltametría de redisolución anódica de pulso diferencial (DPASV) con un HMDE. La zona de muestreo fue elegida en base a su clara influencia antropogénica: se tomó una muestra en la desembocadura del Río Lérez (salinidad 2.2) y las otras tres se tomaron en las proximidades de la Villa de Marín (salinidad 30-32). Las concentraciones de plomo obtenidas fueron de $0.64 \mathrm{nM}$ (muestra de agua dulce) y 4.8-2.9 nM (muestras salinas). Los resultados de la especiación mostraron que los quelatos orgánicos del plomo, 88-95\% del plomo disuelto total, son las especies dominantes del metal incluso a estas elevadas concentraciones. En todas las muestras se detectó la presencia de dos clases de ligandos complejantes del plomo. En la muestra de río se obtuvo un ligando complejante fuerte, de concentración $\sim 7 \mathrm{nM}$, con una constante condicional $\mathrm{K}_{\mathrm{Pb}-\mathrm{L} 1}^{\prime} \geq 10^{11.1}$, y un ligando más débil $\left(\mathrm{K}_{\mathrm{Pb}-\mathrm{L} 2}^{\prime}=10^{8.2}\right)$ de concentración $53.4 \mathrm{nM}$. En las tres muestras de aguas salinas se obtuvieron resultados muy similares: un tipo de ligando fuerte $\left(\mathrm{K}_{\mathrm{Pb}-\mathrm{L} 1}^{\prime} \sim 10^{8.6}\right)$ con una concentracion comprendida entre $33.0 \mathrm{y}$ $53.5 \mathrm{nM}$, y un tipo de ligando complejante del plomo más débil $\left(\mathrm{K}_{\mathrm{Pb}-\mathrm{L} 2}^{\mathrm{L}} \sim 10^{7.5}\right)$ con concentraciones comprendidas entre 32.6 y $50.5 \mathrm{nM}$. Todos los complejos plomo-ligando orgánico (excepto el complejo fuerte de la muestra de río) mostraron un comportamiento lábil en la escala de tiempo de la técnica.

Palabras clave: Plomo, especiación, contaminación, rías, Galicia. 


\section{Introduction}

Estuaries may contain high levels of both heavy metals and organic matter with respect to the open ocean, mainly due to inputs in their margins derived from anthropogenic activities, transported by freshwater and the atmosphere. The irregular Galician coast is very sensitive to the contaminant effects of heavy metals, due to its $1,720-\mathrm{km}$ long littoral and abundant continental inputs carried by rivers and sewage effluents. However, to date there is no detailed information on the metal concentrations and speciation in the Galician rias; only limited studies have been carried out (Guerrero et al., 1988; VidalCollazo, 1991; Antelo, 1992; Vidal-Collazo, 1993; Antelo and Arce, 1996; Cobelo-García et al., 1998a; Cobelo-García et al., 1998b).

The distribution and speciation of metals in seawater is influenced by their total concentration as well as by the organic and inorganic ligands present in the dissolved phase and the co-ordination sites in colloidal and particulate matter (Muller, 1996), and by adsorption sites on the surface of phytoplankton cells (González-Dávila, 1995). Metals in the dissolved phase are present in different physico-chemical forms: (i) free hydrated ion $\left(\mathrm{M}^{\mathrm{z}+}\right)$, (ii) inorganic complexes $\left(\mathrm{MCl}^{\mathrm{z}-1}, \mathrm{MCO}_{3}{ }^{\mathrm{z}-2}\right.$, etc.) and (iii) organic complexes $\left(\mathrm{ML}_{i}\right)$. The speciation of metals in the aquatic environment is of great importance and interest since several studies have shown that bioavailability of trace elements (with respect to toxicity and biolimitation) is generally related to the free or inorganic metal fraction, rather than to total concentration (Sunda and Guillard, 1976; Anderson et al., 1978; Brand et al., 1986; Lorenzo et al., 2002).

It has been widely reported that complexation by organic ligands plays a very important role in the speciation of a lot of metals in estuarine, coastal and oceanic waters; much work has been published, especially for $\mathrm{Zn}$ and $\mathrm{Cu}$ (e.g. van den Berg et al., 1986, 1987; Coale and Bruland, 1988, 1990; Bruland, 1989; Muller and Kester, 1991; van den Berg and Donat, 1992; Donat et al., 1994; Moffett, 1995). The information available for lead in oceanic (Capodaglio et al., 1990, 1991) and coastal and estuarine waters (Muller, 1996; Kozelka et al., 1997; Kozelka and Bruland, 1998; Wells et al., 1998) has also shown that an important fraction of dissolved lead is complexed with organic chelating agents. However, yet there is a lack of information on the lead speciation in areas subjected to metallic contamination. The aim of the present study is to reduce the aforementioned lack of information on lead complexation in the marine environment, especially in those areas with evident anthropogenic inputs and where metal concentrations are high when compared to "typical" or background values.

\section{Methods}

\section{Study site}

The Pontevedra Ria (fig. 1) is one of the biggest Galician rias and is particularly influenced by anthropogenic activities

\section{Introducción}

Los estuarios pueden contener niveles elevados tanto de metales pesados como de materia orgánica disuelta con respecto al mar abierto, debido principalmente a aportes de actividades antropogénicas en su litoral, transportados fluvial y atmosféricamente. La irregular costa gallega es muy sensible a los efectos contaminantes de los metales debido a sus $1720 \mathrm{~km}$ de litoral y a los abundantes aportes terrestres a través de ríos y aguas residuales. Sin embargo, hasta la fecha no existe información detallada sobre la concentración de metales pesados y su especiación en aguas de las cuencas de las rías gallegas, diponiéndose sólo de datos y estudios puntuales (Guerrero et al., 1988; Vidal-Collazo, 1991; Antelo, 1992; Vidal-Collazo, 1993; Antelo y Arce, 1996; Cobelo-García et al., 1998a; Cobelo-García et al., 1998b).

La distribución y especiación de los metales en aguas marinas está influenciada por su concentración total así como por los ligandos orgánicos e inorgánicos presentes en la fase disuelta y lugares de coordinación en la materia coloidal y fases particuladas (Muller, 1996) y por lugares de adsorción en la superficie de células de fitoplancton (González-Dávila, 1995). Los metales en la fase disuelta se presentan en tres diferentes formas físico-químicas: (i) ión libre hidratado $\left(\mathrm{M}^{\mathrm{z}}\right)$, (ii) complejos inorgánicos $\left(\mathrm{MCl}^{\mathrm{z}-1}, \mathrm{MCO}_{3}^{\mathrm{z}-2}\right.$, etc.) y (iii) complejos orgánicos $\left(\mathrm{ML}_{i}\right)$. La especiación de los metales en el medio acuático presenta gran importancia e interés desde que diversos estudios han mostrado que la biodisponibilidad de un metal traza (con respecto a su toxicidad y biolimitación) está generalmente correlacionada a la concentración de metal libre o inorgánico, más que a su concentración total (Sunda y Guillard, 1976; Anderson et al., 1978; Brand et al., 1986; Lorenzo et al., 2002).

Se ha demostrado que la complejación por ligandos orgánicos juega un papel importante en la especiación de muchos metales en aguas estuáricas, costeras y oceánicas, y se han publicado muchos trabajos sobre ello, especialmente para Zn y Cu (e.g. van den Berg et al., 1986, 1987; Coale y Bruland, 1988, 1990; Bruland, 1989; Muller y Kester, 1991; van den Berg y Donat, 1992; Donat et al., 1994; Moffett, 1995). La información disponible para el plomo en aguas oceánicas (Capodaglio et al., 1990, 1991) y aguas costeras y estuáricas (Muller, 1996; Kozelka et al., 1997; Kozelka y Bruland, 1998; Wells et al., 1998) también ha mostrado que una importante fracción del plomo disuelto se encuentra formando quelatos con materia orgánica. Sin embargo, existe todavía una carencia de información sobre la especiación del plomo en zonas donde puede existir una polución metálica puntual. El objetivo del presente trabajo es paliar dicha carencia de información acerca de la complejación del plomo en el medio marino, especialmente en casos donde existen evidencias de aportes antropogénicos, y las concentraciones del metal son elevadas comparadas con los valores "típicos". 


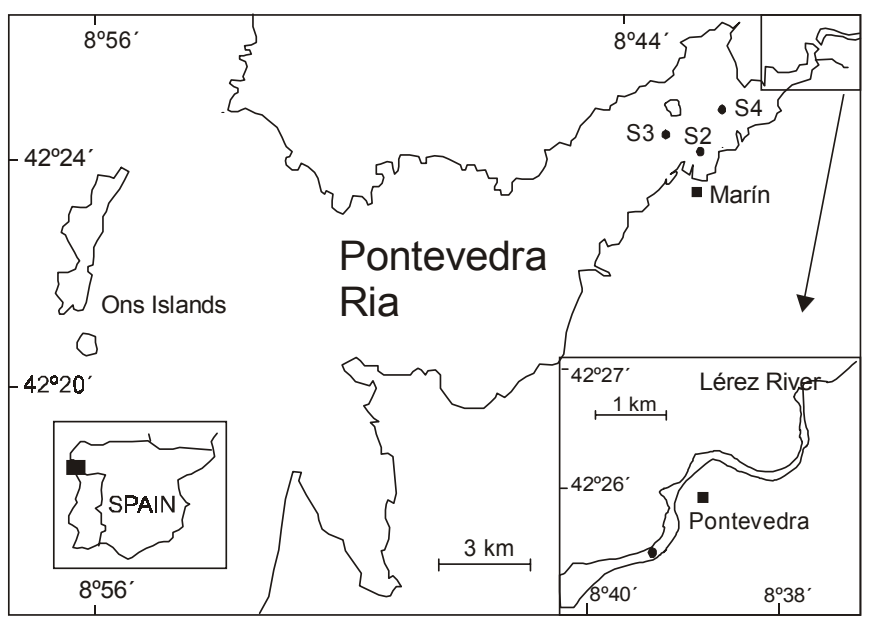

Figure 1. Location of the sampling stations.

Figura 1. Localización de las estaciones de muestreo.

at: (i) the outflow of the Lérez River due to the proximity of the City of Pontevedra (urban sewage) and a wood and a food processing factory; and (ii) near the Village of Marín, where a wood pulp processing and an electrochemical factory as well as an important shipyard are located. In fact, in this inner part of the ria, in the vicinity of Marín, is where the highest anthropogenic impact onn the ria has been reported (Vilas et al., 1996). It is therefore likely to find at this points heavy metal contents in the dissolved phase that exceed the average concentrations for coastal and estuarine waters.

Sample collection, filtration and storage

Samples were collected at four sampling sites in the Pontevedra Ria (fig. 1), in March 1999 (samples 1 and 2, S1 and S2) and March 2000 (samples 3 and 4, S3 and S4). Sampling sites were chosen at points likely to present high concentration of metals. Sample 1 was collected at the outflow of the Lérez River and can be considered as river water (2.2-salinity). Samples 2, 3 and 4 were collected in the vicinity of Marín; lead contamination in this ria is located in this area, as was previously reported from the sediment analysis (Herbello et al., 1998).

One liter acid-cleaned polypropylene (PP) bottles were used for sample collection. Immediately after collection, samples were vacuum-filtered through $0.45-\mu \mathrm{m}$ cellulose acetate filters (Sartorius AG) and stored frozen until analysis. Sample filtration was performed under a laminar flow clean air bench.

\section{Voltammetric equipment}

The voltammetric measurement system consisted of a Metrohm 747 VA Stand, a Metrohm 746 VA Trace Analyzer and a Metrohm 695 Autosampler housed inside a clean laboratory. A hanging mercury dropping electrode (HMDE)

\section{Métodos}

Lugar de estudio

La Ría de Pontevedra (fig. 1) es una de las rías gallegas más grandes y está particularmente influenciada por actividades antropogénicas en: (i) la desenbocadura del Río Lérez, debido a la proximidad de la Ciudad de Pontevedra (vertidos urbanos) y a la presencia de una industria maderera y otra conservera; (ii) cerca de la Villa de Marín, donde se encuentra una fábrica de celulosa y una industria electroquímica, y la salida de la depuradora de aguas de la Ciudad de Pontevedra, así como el puerto de Marín (que es el mayor y más importante de esta ría). De hecho, es en esta parte interna de la ría en los alrededores de Marín donde existe una mayor influencia antropogénica (Vilas et al., 1996). Es, por lo tanto, probable encontrar en estas zonas puntos donde los contenidos de metales pesados en la fase disuelta excedan las concentraciones medias de aguas costeras y estuáricas.

Toma de muestra, filtración y almacenamiento

Las muestras fueron tomadas en cuatro puntos de la ría (fig. 1) en marzo de 1999 (muestras 1 y 2, S1 y S2) y marzo de 2000 (muestras 3 y 4, S3 y S4). La elección de las localidades de muestreo se hizo en base a zonas de la ría que por su situación son susceptibles de presentar niveles altos de metales. La muestra 1 está localizada en la desembocadura del Río Lérez y puede ser considerada prácticamente agua de río (salinidad de 2.2). Las muestras 2, 3 y 4 fueron tomadas en los alrededores de la Villa de Marín. La contaminación por plomo en esta ría se encuentra localizada en esta zona, como ha sido ya mostrado en el análisis de su sedimento (Herbello et al., 1998).

Para la toma de muestra se utilizaron botellas de polipropileno (PP) de $1 \mathrm{~L}$ previamente lavadas con ácido nítrico $2 \mathrm{M}$; inmediatamente después del muestreo, las muestras fueron filtradas a vacío utilizando filtros de acetato de celulosa (Sartorius AG), previamente lavados con ácido, de $0.45 \mathrm{~mm}$ de tamaño de poro, y se almacenaron congeladas hasta sus análisis. La filtración de las muestras se llevó a cabo bajo una campana de aire limpio de flujo laminar.

\section{Equipo voltamétrico}

El sistema voltamétrico de medidas utilizado consistió en un Metrohm 747 VA Stand, un Metrohm 746 VA Trace Analyzer y un Metrohm 695 Autosampler, todo ello situado dentro de un laboratorio limpio. Como electrodo de trabajo se utilizó un electrodo de gota colgante de mercurio (HMDE); como electrodo de referencia se utilizó un electrodo $\mathrm{AgCl} /$ $\mathrm{AgCl}$ ( $\mathrm{KCl}$ sat.), y como electrodo auxiliar se usó uno de platino. Todos los valores de potenciales dados en el trabajo se refieren respecto al electrodo de referencia señalado. Para la determinación de la concentración total de metal se utilizó una celda de borosilicato, mientras que para la valoración de las muestras a su pH natural se utilizó una celda de Teflón. 
was used as working electrode; an $\mathrm{AgCl} / \mathrm{AgCl}$ ( $\mathrm{KCl}$ sat.) as the reference electrode and a platinum wire as auxiliary electrode. A borosilicate cell was used for total metal concentration; a Teflon cell was used for the titration of samples at their natural $\mathrm{pH}$.

Total dissolved lead determination

Concentration of lead was determined using the method of standard additions, with DPASV detection of the metal deposited at $-0.8 \mathrm{~V} v s . \mathrm{Ag} / \mathrm{AgCl}$ ( $\mathrm{KCl}$ sat.). This determination of total dissolved lead needs the breakdown of organic matter (Scarponi et al., 1996) in order to release the organically complexed metal not detected by DPASV. For this purpose, previous to determination, samples were made $1.4 \times 10^{-2} \mathrm{M}$ in $\mathrm{HNO}_{3}$ and $1.6 \times 10^{-2} \mathrm{M}$ in $\mathrm{HClO}_{4}$ reaching a final $\mathrm{pH} \sim 1.5$ and left standing for several weeks. A similar treatment of samples carried out by Duinker and Kramer (1977) with perchloric acid at lower concentrations ( $\mathrm{pH}$ 2.7) showed sufficient for a complete release of complexed lead in river and seawater samples.

Total dissolved concentrations of $\mathrm{Cd}, \mathrm{Zn}$ and $\mathrm{Cu}$ were as well determined following the same procedure.

\section{Chemical speciation: ASV-monitored titration with $\mathrm{Pb}^{+2}$}

Metals can be found, in the dissolved phase of water, in different physico-chemical forms: as inorganic species -free hydrated ion $\left(\mathrm{M}^{\mathrm{z}}\right)$ and complexed with inorganic ligands- or as organic species -forming chelates with the organic matter present-. Lead, as well as other metals, reacts both with inorganic ligands $\mathrm{X}_{i}\left(\mathrm{Cl}^{-}, \mathrm{OH}^{-}, \mathrm{CO}_{3}{ }^{2-}\right.$, etc. $)$ to form $\mathrm{MX}_{i}$ complexes, and with generic organic ligands, L. On the other hand, the ligand $\mathrm{L}$ takes part in protonation reactions and with the major cations present in the medium $\left(\mathrm{Ca}^{2+}, \mathrm{Mg}^{2+}\right.$, etc.). Moreover, it is assumed that the chelate formed by the lead and the organic ligand has a 1:1 stoichiometry $(\mathrm{PbL})$ and does not participate in side-reactions, therefore the involved equilibrium can be presented as follows (Scarponi et al., 1996):

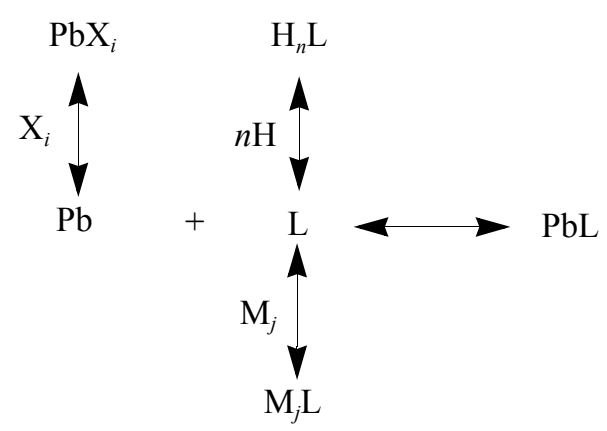

where the stability constant of the complex $\mathrm{Pb}$ is given by $\mathrm{K}=\left[\mathrm{PbL}^{2-\mathrm{n}}\right] /\left[\mathrm{Pb}^{+2}\right]\left[\mathrm{L}^{\mathrm{n}-}\right]$. The constant $\mathrm{K}$ is related to the true or thermodynamic stability constant $\mathrm{K}^{*}$ by the following relationship: $\mathrm{K}=\mathrm{K}^{*}\left(\gamma_{\mathrm{Pb}} \gamma_{\mathrm{L}} / \gamma_{\mathrm{PbL}}\right)$, where $\gamma_{i}$ is the activity
Determinación del plomo total disuelto

La concentración de plomo se determió utilizando el método de adiciones estándar, con la detección mediante la técnica de la voltametría de redisolución anódica (DPASV) del metal depositado a $-0.8 \mathrm{~V}$. Para determinar la concentración total de plomo disuelto es necesaria la destrucción previa de la materia orgánica (Scarponi et al., 1996) para liberar el metal orgánicamente complejado que no es detectado mediante la DPASV. Con este propósito, y previamente a la determinación, se añadieron a las muestras $\mathrm{HNO}_{3}\left(1.4 \times 10^{-2} \mathrm{M}\right)$ y $\mathrm{HClO}_{4}$ $\left(1.6 \times 10^{-2} \mathrm{M}\right)$, alcanzando un $\mathrm{pH}$ final de aproximadamente 1.5 , permitiendo la digestion durante varias semanas. Un tratamiento similar de las muestras, llevado a cabo por Duinker y Kramer (1977) con ácido perclórico a concentraciones menores ( $\mathrm{pH}$ 2.7), mostró ser suficiente para una completa liberación del plomo complejado en aguas marinas y fluviales.

Las concentraciones totales de $\mathrm{Cd}, \mathrm{Zn}$ y $\mathrm{Cu}$ disueltos se determinaron utilizando el mismo procedimiento.

Especiación química: valoración de la muestra con $\mathrm{Pb}^{+2}$ seguida mediante ASV

Los metales pesados pueden encontrarse, en la fase disuelta del agua, en diferentes forman químico-físicas, como especies inorgánicas -metal libre hidratado $\left(\mathrm{M}^{\mathrm{z}}\right)$ y complejos con ligandos inorgánicos- o especies orgánicas -formando quelatos con la materia orgánica complejante presente-. El plomo, al igual que otros metales, va a reaccionar tanto con ligandos inorgánicos $\mathrm{X}_{i}\left(\mathrm{Cl}^{-}, \mathrm{OH}^{-}, \mathrm{CO}_{3}{ }^{2-}\right.$, etc.) para formar complejos de tipo $\mathrm{MX}_{i}$ como con ligandos orgánicos genéricos, L. Por otra parte, el ligando L participa en reacciones de protonación y con los cationes mayoritarios presentes en el medio $\left(\mathrm{Ca}^{2+}, \mathrm{Mg}^{2+}\right.$, etc.). Además, asumimos que el quelato formado entre el plomo y el ligando orgánico es de estequiometría 1:1 (PbL) y no participa en reacciones laterales, por lo que el equilibrio presente se puede expresar de la siguiente manera (Scarponi et al., 1996):

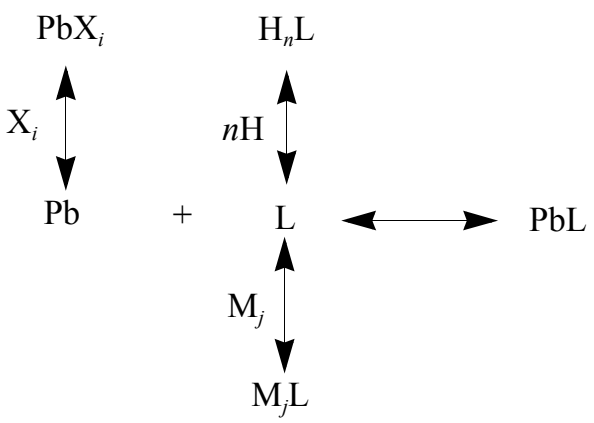

donde la constane de estabilidad del complejo formado viene dada por $\mathrm{K}=\left[\mathrm{PbL}^{2-\mathrm{n}}\right] /\left[\mathrm{Pb}^{+2}\right]\left[\mathrm{L}^{\mathrm{n}}\right]$. La constante $\mathrm{K}$ está relacionada con la constante de estabilidad termodinámica verdadera $\mathrm{K}^{*}$ de acuerdo a la siguiente relación: $\mathrm{K}=\mathrm{K} *\left(\gamma_{\mathrm{Pb}} \gamma_{\mathrm{L}} / \gamma_{\mathrm{PbL}}\right)$, donde $\gamma_{i}$ es el coeficiente de actividad para cada una de las especies. $\mathrm{Si}$ definimos $\left[\mathrm{Pb}^{\prime}\right]$ como la concentración total de plomo 
coefficient of species $i$. If we define [Pb'] as the total lead concentration present in all the inorganic forms (inorganic lead), [L'] as the total organic ligand not complexed with lead, $\alpha_{\mathrm{Pb}}$ as the inorganic side-reaction coefficient for lead $\left(\left[\mathrm{Pb}^{+2}\right]=\left[\mathrm{Pb}^{\prime}\right] / \alpha_{\mathrm{Pb}}\right)$ and $\alpha_{\mathrm{L}}$ as the side-reaction coefficient for the inorganic ligand $\mathrm{L}\left(\left[\mathrm{L}^{\mathrm{n}-}\right]=\left[\mathrm{L}^{\prime}\right] / \alpha_{\mathrm{L}}\right)$, then we can define a conditional stability constant, $\mathrm{K}^{\prime}=[\mathrm{PbL}] /\left[\mathrm{M}^{\prime}\right]\left[\mathrm{L}^{\prime}\right]=\mathrm{K} / \alpha_{\mathrm{Pb}} \alpha_{\mathrm{L}}$, that is related with $\mathrm{K}$ by the side-reaction coefficients.

This voltammetric titration methodology is based on the assumption that the ASV technique allows the inorganic concentration of the metal under study $\left(\left[\mathrm{Pb}^{\prime}\right]\right)$ in a sample to be measured. The present speciation methodology (Scarponi et al., 1996; van den Berg, 1982; Ruzic, 1982) is based on the sample titration with the metal under study; the concentration of inorganic lead detected at any point of the titration can be calculated according to $\left[\mathrm{Pb}^{\prime}\right]=i_{\mathrm{p}} / \mathrm{S}$, where $\mathrm{S}$ is the sensitivity of the ASV technique to labile (inorganic) metal and corresponds to the slope of the titration curve after the natural organic ligands have become saturated with metal, and $i_{\mathrm{p}}$ is the anodic peak current. The calculations of the speciation parameters, ligand concentrations and conditional stability constants were carried out by transformation of the titration curves using the linearization procedures proposed by Ruzic (1982) and van den Berg (1982). According to this method, the ratio $\left[\mathrm{Pb}^{\prime}\right] /[\mathrm{PbL}]$ is plotted against $\left[\mathrm{Pb}^{\prime}\right]$; linearity of this representation over the range of the data was interpreted to indicate complexation of the metal by one class of ligand only. Values for the conditional stability constants with respect to inorganic lead $\left(\mathrm{K}^{\prime}\right)$ and for the concentration of natural metal binding ligand $([\mathrm{L}])$ were obtained from the slope and intercept of the $\left[\mathrm{Pb}^{\prime}\right] /[\mathrm{PbL}] v s$. [Pb'] plot (Ruzic, 1982; van den Berg, 1982; Scarponi et al., 1996):

$$
\frac{\left[\mathrm{Pb}^{\prime}\right]}{\left[\mathrm{Pb}^{\prime}\right]_{\mathrm{T}}-\left[\mathrm{Pb}^{\prime}\right]}=\frac{\left[\mathrm{Pb}^{\prime}\right]}{[\mathrm{L}]}+\frac{1}{\left(\mathrm{~K}_{\mathrm{PbL}}^{\prime}\right) \cdot[\mathrm{L}]}
$$

In the presence of two complexing ligands, the Ruzic/van den Berg transformed representation becomes (van den Berg, 1982; Ruzic, 1982; Scarponi et al., 1996): presente en todas las formas inorgánicas (plomo inorgánico), [L'] como la concentración total de ligando orgánico no unido al plomo, $\alpha_{\mathrm{Pb}}$ como el coeficiente de reacción lateral inorgánico del plomo $\left(\left[\mathrm{Pb}^{+2}\right]=\left[\mathrm{Pb}^{\prime}\right] / \alpha_{\mathrm{Pb}}\right)$ y $\alpha_{\mathrm{L}}$ como el coeficiente de reacción lateral del ligando orgánico $\mathrm{L}\left(\left[\mathrm{L}^{\mathrm{n}}\right]=\left[\mathrm{L}^{\prime}\right] / \alpha_{\mathrm{L}}\right)$, entonces podemos definir una constante condicional de estabilidad, $\mathrm{K}^{\prime}=[\mathrm{PbL}] /\left[\mathrm{M}^{\prime}\right]\left[\mathrm{L}^{\prime}\right]=\mathrm{K} / \alpha_{\mathrm{Pb}} \alpha_{\mathrm{L}}$, que está relacionada con $\mathrm{K}$ por los coeficientes de reacción lateral.

Esta metodología de valoración voltamétrica está basada en la presunción de que la técnica ASV permite medir la concentración inorgánica $\left(\left[\mathrm{M}^{\prime}\right]\right)$ del metal bajo estudio en una muestra. El presente método de especiación (Scarponi et al., 1996; van den Berg, 1982; Ruzic, 1982) está basado en la valoración de la muestra con el metal en estudio, en el cual la concentración de plomo inorgánico detectado en cualquier punto de la valoración puede ser calculado de acuerdo a $\left[\mathrm{Pb}^{\prime}\right]=i_{\mathrm{p}} / \mathrm{S}$, donde $\mathrm{S}$ es la sensibilidad de la técnica ASV al metal lábil (inorgánico) y corresponde a la pendiente de la curva de valoración una vez que los ligandos orgánicos naturales han sido saturados con el metal, e $i_{\mathrm{p}}$ es la intensidad de pico anódica. El cálculo de los parámetros de la especiación, es decir, concentraciones de ligando y constantes condicionales de estabilidad, fueron obtenidos a partir de la transformación de las curvas de valoración utilizando los procedimientos de valoración propuestos por Ruzic (1982) y van den Berg (1982). De acuerdo a este método, se representa $\left[\mathrm{Pb}^{\prime}\right] /[\mathrm{PbL}]$ frente a $\left[\mathrm{Pb}^{\prime}\right] \mathrm{y}$, en el caso de obtener un comportamiento lineal en el intervalo de los datos, esto es indicativo de la complejación del metal por un único tipo de ligando. Los valores para las constantes condicionales de estabilidad con respecto al plomo inorgánico $\left(\mathrm{K}^{\prime}\right)$, y para las concentraciones de los ligandos orgánicos complejantes naturales ([L]), se obtuvieron a partir de la pendiente y de la ordenada en el origen de la gráfica de $\left[\mathrm{Pb}^{\prime}\right] /[\mathrm{PbL}]$ vs. [Pb'] (Ruzic, 1982; van den Berg, 1982; Scarponi et al., 1996):

$$
\frac{\left[\mathrm{Pb}^{\prime}\right]}{\left[\mathrm{Pb}^{\prime}\right]_{\mathrm{T}}-\left[\mathrm{Pb}^{\prime}\right]}=\frac{\left[\mathrm{Pb}^{\prime}\right]}{[\mathrm{L}]}+\frac{1}{\left(\mathrm{~K}_{\mathrm{PbL}}^{\prime}\right) \cdot[\mathrm{L}]}
$$

En presencia de dos ligandos complejantes, la representación transformada tipo Ruzic/van den Berg se convierte en (Ruzic, 1982; van den Berg, 1982; Scarponi et al., 1996):

$$
\frac{\left[\mathrm{Pb}^{\prime}\right]}{\left[\mathrm{Pb}^{\prime}\right]_{\mathrm{T}}-\left[\mathrm{Pb}^{\prime}\right]}=\frac{\left[\mathrm{Pb}^{\prime}\right]}{[\mathrm{L}]_{\mathrm{T}}}+\frac{\left[\mathrm{PbL}_{1}\right]}{\left[\mathrm{PbL}_{1}\right]+\left[\mathrm{PbL}_{2}\right]} \frac{1}{\left(\mathrm{~K}_{\mathrm{PbL}_{1}}^{\prime}\right) \cdot[\mathrm{L}]_{\mathrm{T}}}+\frac{\left[\mathrm{PbL}_{2}\right]}{\left[\mathrm{PbL}_{1}\right]+\left[\mathrm{PbL}_{2}\right]} \frac{1}{\left(\mathrm{~K}_{\mathrm{PbL}_{2}}^{\prime}\right) \cdot[\mathrm{L}]_{\mathrm{T}}}
$$

therefore the plot $\left[\mathrm{Pb}^{\prime}\right] /[\mathrm{PbL}]$ vs. [ $\left.\mathrm{Pb}^{\prime}\right]$ is lineal no more, showing a curvature in the representation. For samples 2, 3 and 4 the Ruzic/van den Berg plot showed a curvature of the type indicating metal complexation by two ligands; the speciation parameters $\left(\mathrm{K}_{\mathrm{PbL} 1}^{\prime},\left[\mathrm{L}_{1}\right], \mathrm{K}_{\mathrm{PbL} 2}^{\prime},\left[\mathrm{L}_{2}\right]\right)$ were estimated using the approach described by van den Berg (van den Berg, 1984; Scarponi et al., 1996). There was no need to invoke more than two ligands in order to accurately reproduce the titration data. por lo que la representación de $\left[\mathrm{Pb}^{\prime}\right] /[\mathrm{PbL}]$ vs. [ $\left.\mathrm{Pb}^{\prime}\right]$ deja de ser lineal y presenta una curvatura. En las muestras 2, 3 y 4, las gráficas Ruzic/van den Berg mostraron una curvatura que indica la complejación del metal por dos ligandos; los parámetros de la especiación $\left(\mathrm{K}_{\mathrm{PbL} 1}^{\prime},\left[\mathrm{L}_{1}\right], \mathrm{K}_{\mathrm{PbL} 2}^{\prime},\left[\mathrm{L}_{2}\right]\right)$ fueron estimados utilizando la aproximación descrita por van den Berg (van den Berg, 1984; Scarponi et al., 1996). No hubo necesidad de ajustar a más tipos de ligandos que para reproducir con precisión los datos de la valoración. 
As was previously mentioned, this methodology of sample titration is based on the ASV technique allowing to measure the inorganic metal concentration. However, there are several situations that may perturb the correct discrimination between the inorganic and organic fractions of metal: (i) the possible reduction of the metal-ligand complex at the applied potential in the deposition step; (ii) the possibility of a kinetic lability of the metal-organic ligand complexes in the diffusion layer (Tuschall and Brezonik, 1981). Both processes would lead to an underestimation of the complexing ligand concentration and the conditional stability constant of the complexes formed.

In order to choose the most suitable deposition potential, minimizing the possible reduction of organically complexed lead, a pseudopolarogram study was carried out for sample 2 . A typical sigmoid shape was obtained from $-0.60 \mathrm{~V}$ to $-1.0 \mathrm{~V}$, confirming that the reduction of the metal-ligand complexes did not occur at that range of potentials. From the pseudopolarogram, a deposition potential of $-0.8 \mathrm{~V}$ was chosen for all the samples, since it was the minimum overpotential required to reach the reproducible fraction of the pseudopolarogram plateau.

The kinetic contribution to the peak current due to the complex dissociation in the diffusion layer depends on the dissociation rate of the complex $\left(\mathrm{k}_{\mathrm{d}}\right)$ and on the effective time scale of the electrochemical experiment, which is also dependent on the residence time of the complex in the diffusion layer. The thinner is the diffusion layer, the shorter the residence time, the lower the dissociation of the complex and, therefore, the lower the kinetic contribution to the peak current. In order to diminish as much as possible the diffusion layer width, the highest stirring rate $(2000 \mathrm{rpm})$ allowed by the electrochemical device without affecting the stability of the mercury drop during the deposition step was used.

Between 12 and 15 lead additions were spiked to every sample to obtain the voltammetric titration, increasing the lead concentration in the sample from 0 to $175 \mathrm{nM}$. After each addition, the samples were allowed to equilibrate for $25 \mathrm{~min}$ utes, avoiding any kinetic effects in the representations due to non-equilibrium conditions (Ruzic and Nikolic, 1982). The deposition times applied were dependent on the labile $\mathrm{Pb}$ concentrations $\left(\left[\mathrm{Pb}^{\prime}\right]\right)$ for every sample and ranged from 2 to 45 minutes. The stripping scan was carried out in the differential pulse mode (DPASV) in the positive direction from $-0.80 \mathrm{~V}$ to $-0.30 \mathrm{~V}$ at a rate of $10 \mathrm{mV} / \mathrm{s}$ with a pulse width of $50 \mathrm{mV}$.

\section{Results}

The total dissolved lead concentrations found were 0.64 in sample 1 (river water), 8.0 in sample 2, 4.8 in sample 3 and 21.9 in sample 4.

Inorganic lead $\left(\mathrm{Pb}^{\prime}\right)$ was not detected in sample 1 even at 45-minute deposition times, until several additions were made, as can be seen in figure 2. This is attributed to the presence of a high-stability lead-organic ligand chelate. The concentration of this strong complexing ligand $\left(\mathrm{L}_{1}\right)$ was estimated (see Bruland
Como se comentó anteriormente, esta metodología de valoración de muestra está basada en que la técnica ASV nos permite medir únicamente la concentración inorgánica de metal. Sin embargo, pueden darse casos que nos pueden alejar de dicha situación debido a (i) la posible reducción del complejo metal-ligando orgánico al potencial aplicado en el paso de deposición; y (ii) una posible labilidad cinética de los complejos del metal con los ligandos orgánicos en la capa de difusión (Tuschall y Brezonik, 1981). Ambos procesos conducirían a una infravaloración de la concentración de ligando complejante y de la constante condicional de estabilidad de los complejos formados.

Para determinar el potencial de deposición más adecuado y que minimice una posible reducción del plomo orgánicamente complejado, se llevó a cabo un pseudopolarograma en la muestra 2. Se obtuvo con éste una forma sigmoidal típica desde $-0.60 \mathrm{~V} \mathrm{a}-1.0 \mathrm{~V}$, por lo que se confirmó la inexistencia de la reducción de los complejos metal-ligando orgánico en ese intervalo de potenciales. Con los resultados obtenidos con el pseudopolarograma, se utilizó un potencial de deposición de $-0,8 \mathrm{~V}$ para todas las muestras, puesto que era el mínimo sobrepotencial necesario para alcanzar la fracción reproducible de la meseta del pseudopolarograma.

La contribución cinética a la intensidad debida a la disociación del complejo en la capa de difusión va a depender de la constante de disociación del complejo $\left(\mathrm{k}_{\mathrm{d}}\right)$ y del tiempo efectivo de medida, el cual a su vez, depende del tiempo que el complejo permanece en la capa de difusión. Cuanto más estrecha sea la capa de difusión, menor será el tiempo de residencia, menor la oportunidad que tendra el complejo de disociarse y, por tanto, menor será la contribución cinética a la intensidad. Con objeto de disminuir todo lo posible el ancho de la capa de difusión y así minimizar dicha contribución cinética, se utilizó la máxima velocidad de agitación $(2000 \mathrm{rpm})$ que permite el equipo voltamétrico sin que se afecte la estabilidad de la gota de mercurio durante la etapa de acumulación.

Para realizar la valoración voltamétrica de la muestra, se realizaron entre 12 y 15 adiciones de la disolución patrón de $\mathrm{Pb}$, por lo que se produce un aumento en la concentración total de $\mathrm{Pb}$ en la muestra desde 0 hasta $175 \mathrm{nM}$. Después de cada adición, se utilizó un período para el equilibrio de 25 minutos, no observándose de esta manera efectos cinéticos en las representaciones, debidos a condiciones de no equilibrio (Ruzic y Nikolic, 1982). Los tiempos de deposición aplicados dependieron de la concentración de $\mathrm{Pb}$ lábil ([Pb']) en cada una de las muestras y variaron de 2 a 45 minutos. El barrido de redisolución se llevó a cabo en el modo de pulso diferencial (DPASV) en la dirección positiva desde $-0.8 \mathrm{~V}$ a $-0.3 \mathrm{~V}$, a una velocidad de $10 \mathrm{mV} / \mathrm{s}$ y con una amplitud de pulso de $50 \mathrm{mV}$.

\section{Resultados}

Las concentraciones totales de plomo disuelto encontradas fueron de $0.64 \mathrm{nM}$ en la muestra 1 (agua de río), $8.0 \mathrm{nM}$ en la muestra $2,4.8 \mathrm{nM}$ en la muestra 3 y $21.9 \mathrm{nM}$ en la muestra 4 . 

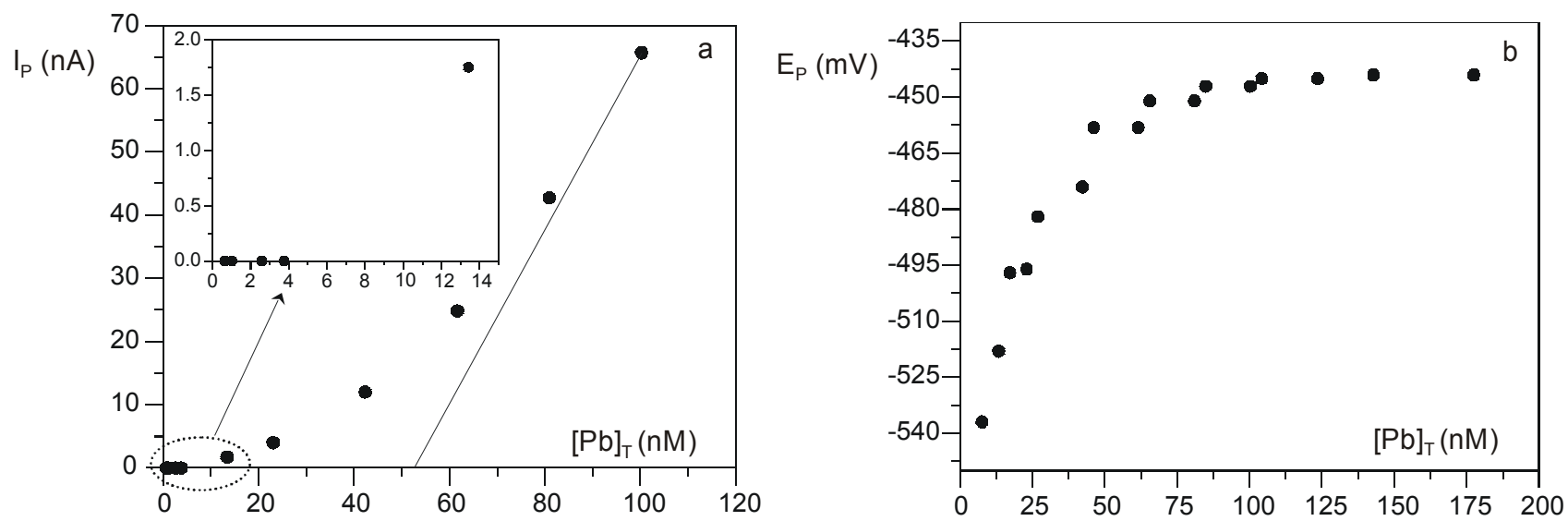

Figure 2. Titration of sample S1 (a); variation of the anodic peak potential of lead with the total lead concentration in several titrations of sample 1 (b). Figura 2. Valoración de la muestra S1 (a); variación del potencial anódico del plomo con la concentración total de plomo en diferentes valoraciones de la muestra S1 (b).

et al., 2000) as the mid-point between the last lead concentration yielding no signal and the lead concentration yielding the first measurable signal, obtaining a concentration $\sim 7 \mathrm{nM}$ (mean of two titrations). In these situations, when no inorganic metal is detected until the ligand is saturated, the product of the conditional stability constant by the ligand concentration is equal or grater than $10^{3}$ (Scarponi et al., 1996). Ignoring the complexation by weaker organic ligands, a low limit for the conditional stability constant can be estimated as $\mathrm{K}_{1}^{\prime} \geq 10^{3} /\left(7 \times 10^{-9}\right)=1.4 \times 10^{11}$. The datapoints obtained for the subsequent $\mathrm{Pb}$ additions during the titration showed a curvature indicative of the presence of one or more types of complexing ligands different to the abovementioned. The transformed plot obtained from these data showed a linear behavior and therefore the presence of only one more ligand was assumed. In order to calculate the concentration of this weaker ligand, the concentration of the stronger ligand was subtracted from every titration point, previous to the transformed plot (Bruland et al., 2000). A concentration of $53.4 \mathrm{nM}$ with a $\log \mathrm{K}^{\prime}=8.2$ was obtained for the weaker ligand. The peak potentials shift towards more anodic values when the total lead concentration increases (fig. 2b), until a constant value is attained corresponding to the peak potential of the free (inorganic) lead, once the second ligand has been completely complexed (saturated). This peak potential shift towards more anodic values indicates that the $\mathrm{Pb}-\mathrm{L}_{2}$ complex is labile or quasi-labile in the timescale of the technique used (van Leeuwen, 1987).

In the saline samples, where a higher total dissolved lead was found, an ambient inorganic lead fraction was detected. The concentrations of the inorganic fractions were $0.54 \mathrm{nM}$ (S2), $0.38 \mathrm{nM}$ (S3) and $2.6 \mathrm{nM}$ (S4), obtaining organically complexed lead percentages of $93.3 \%, 92.1 \%$ and $88.2 \%$, respectively. The Ruzic/van den Berg transformed plot for these saline samples showed a typical curvature for the presence of two types of organic ligands, as can be seen in figure $3 \mathrm{~b}$ for sample 2 . As was previously mentioned, the speciation
En la muestra 1 no se detectó plomo inorgánico $\left(\mathrm{Pb}^{\prime}\right)$, incluso a tiempos de deposición de 45 minutos, hasta que no se hicieron varias adiciones, tal y como se muestra en la figura 2 . Este hecho se atribuye a la presencia de un complejante orgánico del plomo que forma un quelato de elevada estabilidad. La concentración de este ligando complejante fuerte $\left(L_{1}\right)$ puede ser estimada (ver Bruland et al., 2000) a partir del punto medio entre la última concentración de plomo sin obtener señal y la concentración de plomo que produce la primera señal medible, siendo en este caso de $\sim 7 \mathrm{nM}$ (a partir de dos valoraciones). En casos como éste, en el que no se detecta metal inorgánico hasta que el ligando está prácticamente saturado, el producto de la constante condicional de estabilidad por la concentración de ligando es igual o mayor a $10^{3}$ (Scarponi et al., 1996). Ignorando la complejación por ligandos más débiles, podemos estimar un valor mínimo para la constante condicional de estabilidad como $\mathrm{K}_{1}^{\prime} \geq 10^{3 /}\left(7 \times 10^{-9}\right)=1.4 \times 10^{11}$. Los puntos obtenidos por las subsecuentes adiciones de $\mathrm{Pb}$ durante la valoración mostraron una curvatura que indicaba la presencia de uno o varios tipos de ligandos diferentes del anterior. La transformación gráfica de estos datos produjo un comportamiento lineal, por lo que se asumió la presencia de un único ligando más. Para calcular esta concentración de ligando débil, se procedió a la substracción de la concentración de ligando fuerte de la concentración de plomo para cada punto de la valoración, previamente a su transformación gráfica (Bruland et al., 2000). Este ligando más débil presentó una concentración de $53.4 \mathrm{nM}$ con un $\log \mathrm{K}^{\prime}=8.2$ del complejo formado. A partir de la figura $2 \mathrm{~b}$ se puede observar cómo el potencial de pico se desplaza hacia valores anódicos al incrementarse la concentración total de plomo hasta alcanzarse un valor constante que corresponde al potencial del plomo libre (plomo inorgánico), una vez que todo este segundo ligando ha sido complejado (saturado). Este comportamiento de desplazamiento anódico del potencial de pico es indicativo de que este complejo $\mathrm{Pb}-\mathrm{L}_{2}$ es de naturaleza lábil o cuasi-lábil en la escala de tiempo de la técnica utilizada (van Leeuwen, 1987). 

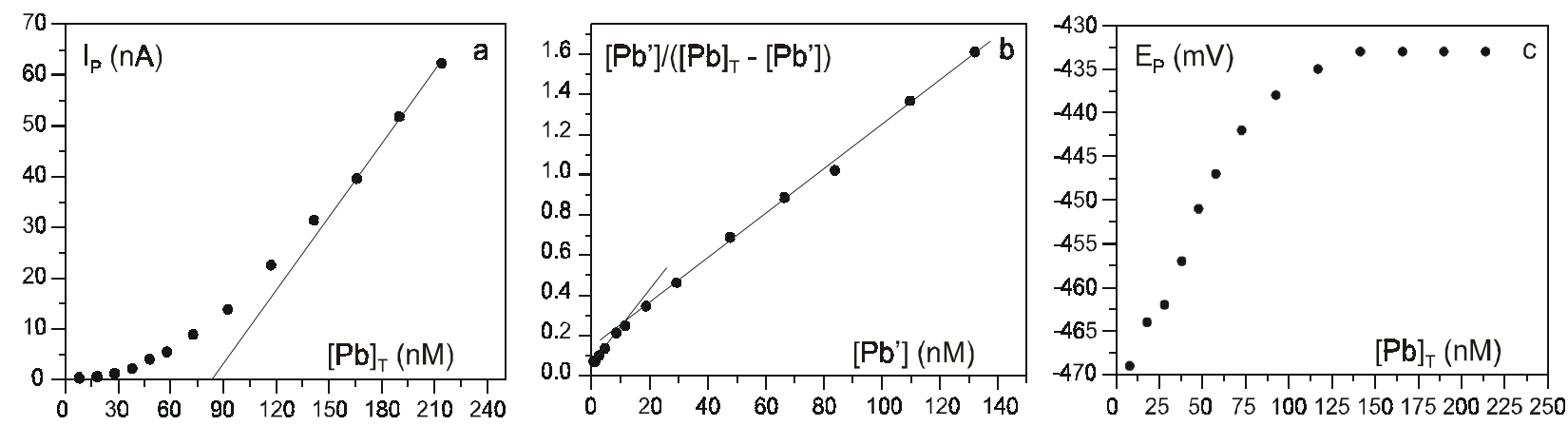

Figure 3. Titration of sample S2 (a); Ruzic/van den Berg transformed plot of the tritration data (b); variation of the anodic peak potential of lead in the titration (c).

Figura 3. Valoración de la muestra S2 (a); gráfica transformada tipo Ruzic/van den Berg de los datos de la valoración (b); variación del potencial de redisolución anódico del plomo durante la valoración (c).

parameters were calculated using the approach proposed by van den Berg (van den Berg, 1984; Scarponi et al., 1996). The concentrations obtained for the "strong" ligands were $53.5 \mathrm{nM}$ (S2), $33.0 \mathrm{nM}(\mathrm{S} 3)$ and $39.4 \mathrm{nM}(\mathrm{S} 4)$, whereas the "weak" ligands concentrations were $37.0 \mathrm{nM}(\mathrm{S} 2), 50.5 \mathrm{nM}(\mathrm{S} 3)$ and $32.6 \mathrm{nM}$ (S4) (table 1). The logarithmic values of the conditional stability constant of the $\mathrm{Pb}-\mathrm{L}_{1}$ complex were around 8.6 and, for the $\mathrm{Pb}-\mathrm{L}_{2}$, around 7.5. As well as for the river sample (S1), a shift of the peak potentials towards more anodic values was observed (fig. 3c), showing a labile or quasi-labile behavior of these complexes in the timescale of the differential pulse anodic stripping voltammetry using a HMDE.

\section{Discussion}

The typical dissolved lead concentrations in coastal and estuarine waters, generally below $1 \mathrm{nM}$ (Cutter, 1991), are widely exceeded in samples 2, 3 and 4, pointing out to the anthropogenic influence in this local area of the inner part of the Pontevedra Ria. These high values are in agreement with the (scarce) existing data that reported lead concentrations in this ria ranging from 2 to $8 \mathrm{nM}$ (Guerrero et al., 1988). This important anthropogenic influence is also evident if we consider the concentrations of $\mathrm{Zn}, \mathrm{Cd}$ and $\mathrm{Cu}$ in those samples (table 2), especially sample $\mathrm{S} 2$, where obvious contamination
En las muestras salinas, en las que se encuentra una mayor concentración total de plomo, sí fue detectada fracción inorgánica del metal en la muestra original. Las concentraciones de dichas fracciones inorgánicas fueron: $0.54 \mathrm{nM}$ (S2, $0.38 \mathrm{nM}$ (S3) y $2.6 \mathrm{nM}$ (S4), obteniéndose un porcentaje de plomo complejado con materia orgánica del $93.3 \%, 92.1 \%$ y $88.2 \%$, respectivamente. La gráfica transformada tipo Ruzic/van den Berg de los datos de la valoración para estas tres muestras salinas mostraron una curvatura típica debida a la presencia de dos clases de ligandos complejantes, como puede observarse en la figura $3 \mathrm{~b}$ para la muestra 2 . Tal y como fuera previamente mencionado, los parámetros de la especiación fueron calculados utilizando la aproximación propuesta por van den Berg (van den Berg, 1984; Scarponi et al., 1996). Los ligandos "fuertes" presentaron concentraciones de $53.5 \mathrm{nM}$ (S2), 33.0 nM (S3) y $39.4 \mathrm{nM}(\mathrm{S} 4)$, mientras que los ligandos "débiles" presentaron concentraciones de $37.0 \mathrm{nM}(\mathrm{S} 2), 50.5 \mathrm{nM}$ (S3) y $32.6 \mathrm{nM}$ (S4) (tabla 1). Los valores logarítmicos de la constante condicional de estabilidad de los complejos $\mathrm{Pb}-\mathrm{L}_{1}$ se encontraron alrededor de 8.6 y para los complejos $\mathrm{Pb}-\mathrm{L}_{2}$ sobre 7.5. Al igual que ocurrió con la muestra de agua de río (S1), se observa un desplazamiento anódico del pico (fig. 3c), poniendo de manifiesto la labilidad o cuasi-labilidad de estos complejos del plomo en la escala de tiempos de la voltametría de redisolción anódica de pulso diferencial utilizando un HMDE.

Table 1. Salinity, lead concentrations and speciation parameters.

Tabla 1. Salinidad, concentraciones de plomo y parámetros de especiación.

\begin{tabular}{lcccccccccc}
\hline Sample & $\mathrm{pH}$ & Salinity & $\begin{array}{c}{[\mathrm{Pb}]_{\mathrm{T}}} \\
(\mathrm{nM})\end{array}$ & $\begin{array}{c}{\left[\mathrm{Pb}^{\prime}\right]} \\
(\mathrm{nM})\end{array}$ & $\begin{array}{c}{\left[\mathrm{L}_{1}\right]} \\
(\mathrm{nM})\end{array}$ & $\begin{array}{c}\log \\
\mathrm{K}_{\mathrm{PbL} 1}^{\prime}\end{array}$ & $\begin{array}{c}{\left[\mathrm{L}_{2}\right]} \\
(\mathrm{nM})\end{array}$ & $\begin{array}{c}\log \\
\mathrm{K}_{\mathrm{PbL} 2}^{\prime}\end{array}$ & $\begin{array}{c}\left.\mathrm{Pb}^{+2-}\right]^{\mathrm{b}} \\
(\mathrm{pM})\end{array}$ & $\begin{array}{c}\text { \%Organic } \\
\mathrm{Pb}\end{array}$ \\
\hline S1 & 7.1 & 2.2 & 0.64 & $<0.03$ & $\sim 7.0$ & $\geq 11.1$ & 53.4 & 8.2 & - & $>95$ \\
S2 & 7.8 & 30.0 & 8.0 & 0.54 & 53.5 & 8.5 & 37.0 & 7.5 & 21.6 & 93.3 \\
S3 & 7.9 & 32.1 & 4.8 & 0.38 & 33.0 & 8.6 & 50.5 & 7.4 & 15.2 & 92.1 \\
S4 & 7.9 & 32.1 & 21.9 & 2.6 & 39.4 & 8.6 & 32.6 & 7.6 & 103.0 & 88.2 \\
\hline
\end{tabular}

aMean of two titrations (resultados obtenidos a partir de la media de dos valoraciones).

bCalculated using (calculado a partir de) $\alpha_{\mathrm{Pb}}=25$ ( (Turner et al., 1981; Byrne et al., 1988). 
Table 2. Total concentrations of zinc, cadmium and copper in the samples. Tabla 2. Concentraciones totales de zinc, cadmio y cobre en las muestras.

\begin{tabular}{lccc}
\hline Sample & {$[\mathrm{Zn}](\mathrm{nM})$} & {$[\mathrm{Cd}](\mathrm{nM})$} & {$[\mathrm{Cu}](\mathrm{nM})$} \\
\hline S1 & 8.0 & 0.19 & 9.6 \\
S2 & 915.0 & 1.17 & 514.0 \\
S3 & 75.5 & 0.35 & 42.5 \\
S4 & 130.0 & 0.26 & 79.1 \\
\hline
\end{tabular}

exists. These data are in accordance with the studies carried out in the sediments of the ria, which reported that the highest anthropogenic influence is located in the vicinity of Marín, mainly due to the shipyard and sewage inputs (Vilas et al., 1996; Herbello et al., 1998). However, the metal concentrations of the river water sample were quite lower than the saline samples, showing that the river is not so influenced by contaminating inputs.

Results show that most of lead ( $>88 \%$ of total dissolved metal) is present as organic complexes in these waters. Two types of organic ligands responsible of that complexation were found in all samples. In the saline samples, the ligands showed a similar behavior, with concentrations of the same order of magnitude and similar conditional stability constants of the $\mathrm{Pb}$-organic ligand complexes $-\log \mathrm{K}_{\mathrm{Pb}-\mathrm{L} 1}^{\prime} \sim 8.6$ and $\log \mathrm{K}_{\mathrm{Pb}-\mathrm{L} 2}^{\prime}$ $\sim 7.5$, not showing any temporal trend. However, the fluvial sample (S1), in spite of showing also two types of ligands, they showed different characteristics with respect to those of the saline samples. Accordingly, the conditional stability constant of the "strong" ligand was quite greater $\left(\log \mathrm{K}_{\mathrm{Pb}-\mathrm{L} 1} \geq 11.1\right)$ and its concentration lower $(\sim 7 \mathrm{nM})$; the conditional stability constant of the "weak" ligand was greater $\left(\log \mathrm{K}_{\mathrm{Pb-L} 2}^{\prime}=8.2\right)$, although its concentration was of the same order as the ligands of the saline samples.

It is important to point out that the ligands (except the "strong" one in sample S1) showed a labile or quasi-labile behavior in the timescale of the HMDE electrode, which may lead to an underestimation of the conditional stability constant of the complexes detected, although the ligand concentrations are not affected (Capodaglio et al., 1995). Another consequence of the complex lability is that the labile metal concentration $\left(\left[\mathrm{Pb}^{\prime}\right]\right)$-and, therefore $\left[\mathrm{Pb}^{+2}\right]$ - is overestimated, whereas the $\% \mathrm{~Pb}_{\text {organic }}$ is underestimated. This labile behavior of the organic complexes when using a HMDE was also reported by Botelho et al. (1994) in a previous study carried out on the lead complexation with organic ligands in contaminated river waters.

On the other hand, no obvious correlation was found between the total lead concentration and the ligand concentrations, as observed in figure 4. However, a slight decrease in the total ligand concentration when increasing the metal concentration is observed for the saline samples, although the scarce data available do not allow to go deeper in this observation.

\section{Discusión}

Las concentraciones típicas de plomo disuelto en aguas costeras y estuáricas, normalmente menores a $1 \mathrm{nM}$ (Cutter, 1991), son ampliamente superadas en las muestras 2, 3 y 4 presentadas en este estudio, lo que pone de manifiesto la influencia antropogénica en esta zona interna de la Ría de Pontevedra. Estos valores altos están en concordancia con los escasos datos puntuales existentes que señalaban la existencia de concentraciones de plomo en esta ría entre 2 y $8 \mathrm{nM}$ (Guerrero et al., 1988). La marcada influencia antropogénica en esta zona de la ría también se pone de manifiesto en las concentraciones de $\mathrm{Zn}, \mathrm{Cd} \mathrm{y} \mathrm{Cu}$ en dichas muestras (tabla 2), especialmente en la $\mathrm{S} 2$, donde existe una clara contaminación. Estos datos están en correlación con los estudios existentes de metales en el sedimento de la ría, que ponen de manifiesto que la mayor influencia antropogénica se encuentra en la zona próxima a Marín debido principalmente al puerto y a los vertidos allí realizados (Vilas et al., 1996; Herbello et al., 1998). Sin embargo, la muestra de agua de río presentó concentraciones de metales mucho menores que las muestras salinas, por lo que parece que el río no está tan influenciado por la contaminación.

Los resultados muestran que el plomo se encuentra mayoritariamente formando complejos orgánicos en estas aguas ( $>88 \%$ del metal total disuelto) incluso a elevadas concentraciones de hasta $22 \mathrm{nM}$ (tabla 1). En todas las muestras se encontraron dos tipos de ligandos orgánicos responsables de dicha complejación. En las muestras salinas, los ligandos mostraron un comportamiento similar, con concentraciones del mismo orden y con prácticamente las mismas constantes condicionales de estabilidad de los complejos Pb-ligando orgánico $-\log \mathrm{K}_{\mathrm{Pb}-\mathrm{L} 1}^{\prime} \sim 8.6$ y $\log \mathrm{K}_{\mathrm{Pb}-\mathrm{L} 2}^{\prime} \sim 7.5$, sin observarse variaciones temporales. Sin embargo, la muestra fluvial (S1), aunque mostró también la presencia de dos tipos de ligandos, éstos son de características diferentes con respecto a los de las muestras salinas. En efecto, el ligando "fuerte" presentó una constante condicional de estabilidad mucho mayor $\left(\log \mathrm{K}_{\mathrm{Pb}-\mathrm{L} 1}^{\prime} \geq 11.1\right) \mathrm{y}$ una concentración menor $(\sim 7 \mathrm{nM})$. Asimismo, el ligando "débil" mostró una constante condicional de estabilidad mayor $\left(\log \mathrm{K}_{\mathrm{Pb}-\mathrm{L} 2}^{\prime}=8.2\right)$ aunque su concentración se encontraba dentro del orden de los ligandos de las muestras salinas.

Es importante señalar que los ligandos presentes en las muestras (excepto el "fuerte" en la muestra de agua dulce) mostraron un comportamiento lábil o cuasi-lábil en la escala de tiempos de un electrodo HMDE, lo cual conduce a infravaloraciones de la constante condicional de estabilidad de los complejos detectados, aunque los valores de las concentraciones de ligandos no se suelen ver afectados (Capodaglio et al., 1995). Otra consecuencia de la labilidad de los complejos es el hecho de que la concentración de metal lábil $\left(\left[\mathrm{Pb}^{\prime}\right]\right)-\mathrm{y}$ por ende, $\left[\mathrm{Pb}^{+2}\right]$ - es sobreestimada, mientras que el valor de $\% \mathrm{~Pb}_{\text {or- }}$ gánico es infravalorado. Este comportamiento lábil de los complejos orgánicos del plomo en un HMDE también fue reportado por Botelho et al. (1994) en estudios llevados a cabo 


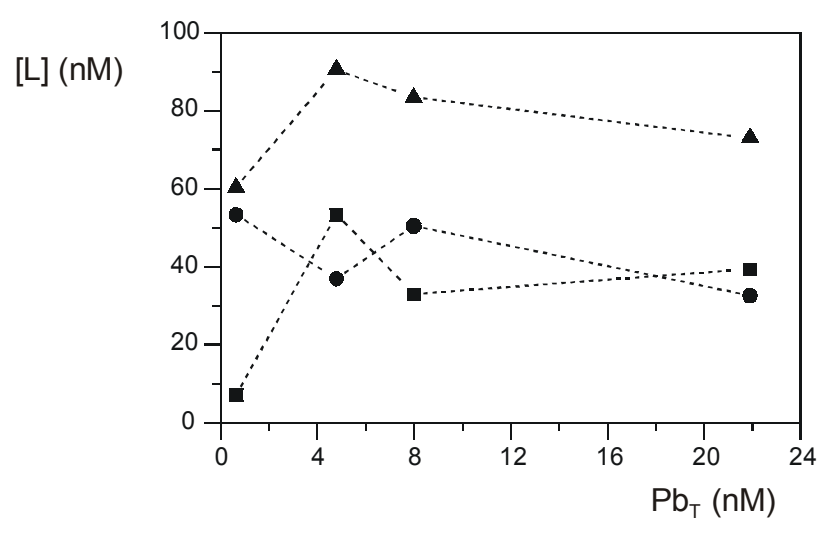

Figure 4. Variation of the organic ligand concentrations with the lead concentration; $\boldsymbol{\nabla}\left[\mathrm{L}_{1}\right](\mathrm{nM}), \bullet\left[\mathrm{L}_{2}\right](\mathrm{nM}), \boldsymbol{\Delta}\left[\mathrm{L}_{\mathrm{T}}\right](\mathrm{nM})$.

Figura 4. Variación de las concentraciones de ligandos orgánicos con la concentración de plomo; $\mathbf{\square}\left[\mathrm{L}_{1}\right](\mathrm{nM}), \bullet\left[\mathrm{L}_{2}\right](\mathrm{nM}), \boldsymbol{\Delta}\left[\mathrm{L}_{\mathrm{T}}\right](\mathrm{nM})$.

Contribution to the knowledge of lead speciation in coastal areas. Comparison with data in literature.

The studies published on chemical lead speciation in estuarine and coastal waters (Muller, 1996; Kozelka et al., 1997; Kozelka and Bruland, 1998; table 3) also reported the presence of two types of organic complexing ligands responsible for, usually, more than $90 \%$ of total dissolved lead. This is also confirmed in the present study, suggesting that most of dissolved lead in the estuarine-coastal environment is organically complexed even at high concentrations up to $22 \mathrm{nM}$. However, there are several differences with the data reported in the literature:

(i) In the present study we have sampled an area where an evident anthropogenic influence exists and therefore the $\mathrm{Pb}$ sobre la complejación del plomo con ligandos orgánicos en agua de río contaminado.

Hay que señalar también que no existe una correlación obvia entre la concentración total de plomo y la concentración de ligandos (fig. 4). Sin embargo, en las muestras salinas sí parece apreciarse un descenso en la concentración total de ligando al aumentar la concentración de metal, aunque los escasos datos disponibles no permiten ahondar más en dicha observación.

Aportación al conocimiento de la especiación litoral del $\mathrm{Pb}$. Comparación con datos existentes en la bibliografía.

Los estudios existentes de la especiación química del plomo en aguas estuáricas y costeras (Muller, 1996; Kozelka et al., 1997; Kozelka y Bruland, 1998; tabla 3) coinciden en señalar la presencia de dos ligandos orgánicos complejantes del plomo responsables de la complejación de, normalmente, más del $90 \%$ del plomo total disuelto. Este hecho se confirma también con lo expuesto en este trabajo, por lo que parece que la mayor parte del plomo en el medio estuárico-costero se encuentra complejado con materia orgánica incluso a las elevadas concentraciones aquí encontradas de hasta $22 \mathrm{nM}$. Sin embargo, existen algunas diferencias con los datos bibliográficos que destacamos a continuación:

(i) En el presente estudio hemos muestreado una zona donde existe una influencia antropogénica clara, siendo la concentracion de $\mathrm{Pb}$ mayor en un factor de un orden de magnitud con respecto a los datos bibliográficos expuestos; (ii) las concentraciones de ligando son hasta 2 órdenes de magnitud mayores. Una posible explicación a este hecho es la producción de exudados complejantes de metales por parte del plancton marino expuesto a estas elevadas concentraciones metálicas (Ahner y Morel, 1995). Sin embargo, la razón más

Table 3. Comparison of dissolved lead speciation values in coastal and estuarine surface waters.

Tabla 3. Comparación de los valores de la especiación del plomo disuelto en aguas superficiales costeras y estuáricas.

\begin{tabular}{|c|c|c|c|c|c|c|c|c|c|c|}
\hline Location & Salinity & $\begin{array}{l}\text { Filtration } \\
\text { pore-size }\end{array}$ & $\begin{array}{l}{[\mathrm{Pb}]_{\mathrm{T}}} \\
(\mathrm{nM})\end{array}$ & $\begin{array}{l}{\left[\mathrm{Pb}^{\prime}\right]} \\
(\mathrm{nM})\end{array}$ & $\begin{array}{l}{\left[\mathrm{L}_{1}\right]} \\
(\mathrm{nM})\end{array}$ & $\begin{array}{c}\log \\
\mathrm{K}_{\mathrm{PbL} 1}^{\prime}\end{array}$ & $\begin{array}{l}{\left[\mathrm{L}_{2}\right]} \\
(\mathrm{nM})\end{array}$ & $\begin{array}{c}\log \\
\mathrm{K}_{\mathrm{PbL} 2}^{\prime}\end{array}$ & $\begin{array}{c}\% \text { Organic } \\
\mathrm{Pb}^{\mathrm{a}}\end{array}$ & Technique $^{\mathrm{b}}$ \\
\hline $\begin{array}{l}\text { Narragansett Bay, } \\
\text { Rhode Island, USA }{ }^{1}\end{array}$ & $23-30$ & $0.2 \mu \mathrm{m}$ & $0.13-0.32$ & n.d. -0.01 & $0.6-1.0$ & $9.9-10.2$ & $5.1-8.2$ & $8.6-8.8$ & $>90(95)$ & $\begin{array}{c}\text { DPASV } \\
\text { TMF-RGCDE }\end{array}$ \\
\hline Southern English Coast ${ }^{2}$ & $20-35$ & $0.4 \mu \mathrm{m}$ & $0.20-2.1$ & n.d. -1.65 & $0.1-0.9$ & $9.7-11.1$ & $2-14$ & $8.0-9.3$ & $0-96(70)$ & $\begin{array}{c}\text { DPASV } \\
\text { TMF-RGCDE }\end{array}$ \\
\hline $\begin{array}{l}\text { South San Francisco Bay, } \\
\text { USA }^{3} \text {, one sample }\end{array}$ & 27.3 & $0.2 \mu \mathrm{m}$ & 0.20 & 0.007 & 0.89 & 10.5 & 12.8 & 8.6 & 97 & $\begin{array}{c}\text { DPASV } \\
\text { TMF-RGCDE }\end{array}$ \\
\hline \multirow[t]{2}{*}{$\begin{array}{l}\text { Pontevedra Ría, Galicia, } \\
\text { (NW Spain)-this study }\end{array}$} & $30.0-32.1$ & $0.45 \mu \mathrm{m}$ & $4.8-21.9$ & $0.38-2.6$ & $33.0-53.5$ & $8.5-8.6$ & $32.6-50.8$ & $7.4-7.6$ & $88-93(91)$ & $\begin{array}{l}\text { DPASV } \\
\text { HMDE }\end{array}$ \\
\hline & 2.2 & $0.45 \mu \mathrm{m}$ & 0.64 & $<0.03$ & $\sim 7$ & $\geq 11.1$ & 53.4 & 8.2 & $>95$ & \\
\hline
\end{tabular}

aMean values in brackets (valores medios entre paréntesis).

bDPASV: Differential Pulse Anodic Stripping Voltammetry (Voltametría de Redisolución Anódica de Pulso Diferencial).

TMF-RGCDE: Thin Mercury Film - Rotating Glassy Carbon Disk Electrode (Electrodo Rotatorio de Carbono Vitreo con Película de Mercurio).

HMDE: Hanging Mercury Dropping Electrode (Electrodo de Gota Colgante de Mercurio).

${ }^{1}$ Kozelka and Bruland, 1998; ${ }^{2}$ Muller, 1996; ${ }^{3}$ Kozelka et al., 1997. 
concentrations are one order of maginitude greater than the literature data cited; (ii) ligand concentrations are up to two orders of magnitude greater. One possible reason is the production of complexing exudates from marine phytoplankton exposed to those high metal concentrations (Ahner and Morel, 1995). However, the most probable reason of these high ligand concentrations is that most of the complexing organic matter has (as well as most of the lead present) an anthropogenic origin, from the sewage inputs to the ria. In the sampling area, a wood pulp processing factory and a sewage treatment plant are settled, contributing with high loads of organic matter to this area. In fact, previous studies have shown that sediments in the vicinity of Marín contain the greatest organic load (up to 19\%) in the whole ria (Vilas et al., 1996); (iii) the stability constants of the two types of organic complexes found are around 10 times lower; this is coherent if we take into account that at these high lead concentrations the stronger ligands, of lower concentration, are completely saturated before the titration; that is, the analytical windows (van den Berg and Donat, 1992; Bruland et al., 2000) used are different. This makes sense if we compare the strong complexation constants obtained in the Pontevedra Ria $(8.5$ - 8.6) with the weak constants reported for Narragansett Bay (8.6 - 8.8), the Southern English Coast $(8.0-9.3)$ and the San Francisco Bay (8.6), being all very similar.

\section{Acknowledgements}

The authors thank R. Beiras and J.I. Lorenzo from the Grupo de Ecoloxía of the Facultade de Ciencias (Universidade de Vigo) for their help with the sampling and determination of $\mathrm{pH}$ and salinity. A. Cobelo-García would like to thank the Spanish Ministry of Science and Technology for the financial support (FPI Grant).

\section{References}

Ahner, B.A. and Morel, F.M.M. (1995). Phytochelatin production in marine algae. 2. Induction by various metals. Limnol. Oceanogr., 40(4): 658-665.

Anderson, M.A., Morel, F.M.M. and Guillard, R.R.L. (1978). Growth limitation of a coastal diatom by low zinc ion activity. Nature, 276: 70.

Antelo, J.M. (1992). Calidad del agua en las Estaciones de Aforos de los Ríos de Galicia Costa, Años Hidrológicos 89-90 y 90-91. FEUGA, Xunta de Galicia.

Antelo, J.M. and Arce, F. (1996). Características fisicoquímicas das Augas Superficiais. In: Consello da Cultura Galega (ed.), As Augas de Galicia, pp. 351-446.

Botelho, C.M.S., Boaventura, R.A.R. and Goncalves, M.L.S.S. (1994). Interactions of lead (II) with natural river water: part I. Soluble organics. Sci. Tot. Environ., 149: 69-81.

Brand, L.E., Sunda, W.G. and Guillard, R.R.L. (1986). Reduction in marine phytoplankton reproduction rates by copper and cadmiun. J. Exp. Mar. Biol. Ecol., 96: 225-250.

Bruland, K.W. (1989). Complexation of zinc by natural organic ligands in the central North Pacific. Limnol. Oceanogr., 34(2): 269-285. probable de estas elevadas concentraciones de ligandos orgánicos es que la mayor parte de esta materia orgánica complejante tenga (al igual que gran parte del metal presente) un origen antropogénico de los vertidos que se realizan a la ría. Hay que señalar que sobre la zona donde se tomaron las muestras salinas se produce la descarga de las aguas provenientes de una industria de celulosa y de una planta de tratamiento de agua, lo que debe suponer un aporte importantísimo de materia orgánica en la zona. De hecho, estudios realizados en el sedimento de la ría (Vilas et al., 1996) muestran que estas zonas próximas a la Villa de Marín son las que presentan un mayor contenido en materia orgánica, hasta del 19\%; (iii) las constantes de estabilidad de los dos tipos de complejos orgánicos encontrados son del orden de 10 veces menores para ambos casos, lo cual es lógico si tenemos en cuenta que al trabajar con concentraciones mayores de plomo, los ligandos más fuertes, de menor concentración, se hallan totalmente saturados previamente a la valoración; esto es, las ventanas analíticas (van den Berg y Donat, 1992; Bruland et al., 2000) utilizadas son diferentes. Esto tiene sentido si comparamos las constantes de complejación fuertes obtenidas en la Ría Pontevedra (8.5-8.6) con las débiles reportadas en la literatura para Narragansett Bay (8.6-8.8), la Costa Sur Inglesa (8.0-9.3) y la Bahía de San Francisco (8.6), siendo ambas muy similares.

\section{Agradecimientos}

Los autores agradecen a R. Beiras y J.I. Lorenzo del Grupo de Ecología de la Facultad de Ciencias de la Universidad de Vigo su ayuda con las muestras y la determinación de $\mathrm{pH}$ y salinidad. A. Cobelo-García agradece al Ministerio de Ciencia y Tecnología español por el apoyo financiero (Beca FPI).

Traducido al español por los autores.

Bruland, K.W., Rue, E.L., Donat, J.R., Skrabal, S.A. and Moffet, J.W. (2000). Intercomparison of voltammetric techniques to determine the chemical speciation of dissolved copper in a coastal seawater sample. Anal. Chim. Acta, 405: 99-113.

Byrne, R., Kump, L.R. and Cantrell, K.J. (1988). The influence of $\mathrm{pH}$ and temperature on trace metal speciation in seawater. Mar. Chem., 25: 163-181.

Capodaglio, G., Coale, K.W. and Bruland, K.W. (1990). Lead speciation in surface waters of the Eastern North Pacific. Mar. Chem., 29: 221-233.

Capodaglio, G., Scarponi, G. and Cescon, P. (1991). Lead speciation in the Antarctic Ocean. Analyt. Proc., 28: 76-77.

Capodaglio, G., Scarponi, G. and Cescon, P. (1995). Speciation of trace metals in seawater by anodic stripping voltammetry: critical analytical steps. Fresenius J. Anal. Chem., 351: 386-392.

Coale, K.H. and Bruland, K.W. (1988). Copper complexation in the northeast Pacific. Limnol. Oceanogr., 33(5): 1084-1101.

Coale, K.H. and Bruland, K.W. (1990). Spatial and temporal variability in copper complexation in the North Pacific. Deep-Sea Res., 37(2): 317-336. 
Cobelo-García, A., Prego, R., Fernández-Álvarez, J.M. (1998a). Estudio voltamétrico de los parámetros de complejación del zinc en aguas de las rías gallegas. Series de Química Oceanográfica Serie II Cuadernos, 2: 17-25.

Cobelo-García, A, Fernández-Álvarez, J.M. and Prego, R. (1998b). In: Universidade de Faro (ed.), Proccedings of the 1st Interdisciplinary Symposium on Estuarine Processes. Faro (Portugal), pp.105-108.

Cutter, G.A. (1991). Trace elements in estuarine and coastal waters: United States studies from 1986-1990. Rev. Geophys., 29: 639644.

Donat, J.R., Lao, K.A. and Bruland, K.W. (1994). Speciation of dissolved copper and nickel in South San Francisco Bay: a multimethod approach. Anal. Chim. Acta, 284: 547-571.

Duinker, J.C. and Kramer, C.J.M. (1977). An experimental study on the speciation of dissolved zinc, cadmiun, lead and copper in river Rhine and North Sea water, by differential pulsed anodic stripping voltammetry. Mar. Chem., 5: 207-228.

González-Dávila, M. (1995). The role of phytoplancton cells on the control of heavy metal concentration in seawater. Mar. Chem., 48: 215-236.

Guerrero-Pérez, J., Rodríguez-Puente, C. y Jornet-Sancho, A. (1988). Estudio de metales pesados en aguas y sedimentos superficiales en las costas cantábrica y gallega. Informes Técnicos Instituo Español de Oceanografía, $n^{\circ} 64$.

Herbello, P., Barciela, M.C., Prego, R. and Bermejo, P. (1998). In: Morales and Borrego, (eds.), European Land-Ocean Interaction Studies. Huelva, Spain, p. 62.

Kozelka, P.B., Sanudo-Wilhelmy, S., Flegal, A.R. and Bruland, K.W. (1997). Physico-chemical speciation of lead in South San Francisco Bay. Estuar. Coast. Shelf Sci., 44: 649-658.

Kozelka, P.B. and Bruland, K.W. (1998). Chemical speciation of dissolved $\mathrm{Cu}, \mathrm{Zn}, \mathrm{Cd}, \mathrm{Pb}$ in Narragansett Bay, Rhode Island. Mar. Chem., 60: 267-282.

Lorenzo, J.I., Beiras, R. and Nieto, O. (2002). Effects of humic acids on speciation and toxicity of copper to Paracentrotus lividus larvae in seawater. Aquatic Toxicology, 58: 27-41.

Moffett, J.W. (1995). Temporal and spatial variability of copper complexation by strong chelators in the Sargasso Sea. Deep-Sea Res., 42 (8): 1273-1295.

Muller, F.L.L. and Kester, D.R. (1991). Voltammetric determination of the complexation parameters of zinc in marine and estuarine waters. Mar. Chem., 33: 71-90.

Muller, F.L.L. (1996). Interactions of copper, lead and cadmiun with the dissolved, colloidal and particulate components of estuarine and coastal waters. Mar. Chem., 52: 245-268.

Ruzic, I. (1982). Theoretical aspects of the direct titration of natural waters and its information yield for trace metal speciation. Anal. Chim. Acta, 140: 99-113.

Ruzic, I. and Nikolic, S. (1982). The influence of kinetics on the direct titration curves on natural water systems. Theoretical considerations. Anal. Chim. Acta, 140: 331-334.
Scarponi, G., Capodaglio, G., Barbante, C. and Cescon, P. (1996). In: S. Caroli (ed.), Element Speciation in Bioinorganic Chemistry. John Wiley and Sons, Inc., pp. 363-418.

Sunda, W.G. and Guillard, R.R.L. (1976). The relationship between cupric ion activity and the toxicity of copper to phytoplankton. J. Mar. Res., 34: 511-529.

Turner, D.R., Whitfield, M. and Dickson, A.G. (1981). The equilibrium speciation of dissolved components in freshwater and seawater at $25^{\circ} \mathrm{C}$ and $1 \mathrm{~atm}$ pressure. Geochim. Cosmochim. Acta, 45: $855-882$.

Tuschall, J.R. and Brezonik, P.L. (1981). Evaluation of copper anodic stripping voltammetry complexometric titration for complexing capacities and conditional stability constants. Anal. Chem., 53: 1986-1989.

van den Berg, C.M.G. (1982). Determination of copper complexation with natural organic ligands in seawater by equilibration with $\mathrm{MnO}_{2}$ : I. Theory. Mar. Chem., 11: 307-322.

van den Berg, C.M.G. (1984). Determination of the complexing capacity and conditional stability constants of complexes of copper (II) with natural organic ligands in seawater by cathodic stripping voltammetry of copper-cathecol complex ions. Mar. Chem., 15: 1-18.

van den Berg., C.M.G., Buckley, P.H.M., Huang, Z.Q. and Nimmo, M. (1986). An electrochemical study of the speciation of copper, zinc and iron in two estuaries in England. Estuar. Coast. Shelf Sci., 22: 479-486.

van den Berg., C.M.G., Merks, A.G.A. and Duursma, E.K. (1987). Organic complexation and its control of the dissolved concentrations of copper and zinc in the Scheldt estuary. Estuar. Coast. Shelf Sci., 24: 785-797.

van den Berg, C.M.G. and Donat, J.R. (1992). Determination and data evaluation of copper complexation by organic ligands in sea waater using cothodic stripping voltammetry at varying detection windows. Analyt. Chim. Acta, 257: 281-291.

van Leeuwen, H.P. (1987). Voltammetric titrations involving metal complexes: effect of kinetics and diffusion coefficients. Sci. Tot. Environ., 60: 45-55.

Vidal-Collazo, M.L. (1991). Especiación de Zn, Cd, $\mathrm{Pb}$ y Cu en aguas de la ría de Ferrol. Series de Química Oceanográfica - Serie II Cuadernos, 3: 1-54.

Vidal-Collazo, M.L. (1993). Cálculo de las capacidades de complejación de cobre en aguas superficiales de las rías de $\mathrm{O}$ Burgo y Ferrol. Series de Química Oceanográfica - Serie II Cuadernos, 2/3: 77-85.

Vilas, F., García-Gil, E., García-Gil, S., Nombela, M.A., Alejo, I., Rubio, B. y Pazos, O. (1996). Cartografía de sedimentos submarinos - Ría de Pontevedra. Xunta de Galicia, 39 pp.

Wells, M.L., Kozelka, P.B. and Bruland, K.W. (1998). The complexation of 'dissolved' $\mathrm{Cu}, \mathrm{Zn}, \mathrm{Cd}$ and $\mathrm{Pb}$ by soluble and colloidal organic matter in Narragansett Bay, RI. Mar. Chem., 62: 203-217. 